\title{
Efektivitas Minyak Sereh Wangi dalam Mengendalikan Kutu Putih Pepaya Paracoccus marginatus L.
}

\section{The Effectiveness of Citronella Oil in Controlling Papaya Mealybug Paracoccus marginatus L.}

\section{Liza Octriana*, Mizu Istianto}

\author{
Balai Penelitian Tanaman Buah Tropika, Jl.Raya Solok-Aripan X Koto Singkarak km.8, Solok 27301, Sumatera \\ Barat, Indonesia \\ *E-mail Penulis Korespondensi: lizaoctriana@ymail.com
}

\begin{abstract}
One of the problems in papaya cultivation is the high attack of pests and diseases. The mealybug, P. marginatus L (Hemiptera: Pseudococcidae) is currently found to attack papaya plants. The infestation of mealybugs greatly affects the yield and quality of fruits. The purpose of this study was to determine the effect of the concentration of citronella oil on mealybugs on papaya plants. The study for the observation of mortality and fecundity used a Randomized Block Design (RAK), with 4 treatment levels of citronella oil concentration, namely 0 (control), $0.5 \mathrm{~mL} / \mathrm{L}, 1 \mathrm{~mL} / \mathrm{L}$ and $2 \mathrm{~mL} / \mathrm{L}$. Observation parameters included preference level of papaya mealybugs on the aroma of citronella oil, repellency, fecundity and mortality of mealybugs, with the application of citronella oil. The results showed that citronella oil has the potential to be used to control papaya mealybugs. The application of citronella oil at concentrations of $0.5,1$ and $2 \mathrm{~mL} / \mathrm{L}$ showed repellent activity against mealybugs, reducing fecundity and causing mortality. The higher the concentration of citronella oil applied, the more potential to control mealybugs. However, the application of citronella oil must be considered for its impact on plants. Too high a concentration can cause toxicity to plants.
\end{abstract}

Keywords: Citronella oil, mealybug, papaya

\section{ABSTRAK}

Salah satu kendala dalam budidaya pepaya adalah tingginya serangan hama dan penyakit. Kutu putih, P. marginatus $\mathrm{L}$ (Hemiptera: Pseudococidae) saat ini ditemukan banyak menyerang tanaman pepaya. Infestasi hama kutu putih sangat berpengaruh terhadap produksi dan kualitas buah. Tujuan dari penelitian ini adalah untuk mengetahui pengaruh konsentrasi minyak serai wangi terhadap kutu putih pada tanaman pepaya. Penelitian untuk pengamatan mortalitas dan keperidian menggunakan Rancangan Acak Kelompok (RAK), dengan 4 taraf perlakuan konsentrasi minyak sereh wangi, yaitu 0 (kontrol), $0,5 \mathrm{~mL} / \mathrm{L}, 1 \mathrm{~mL} / \mathrm{L} \mathrm{dan} 2 \mathrm{~mL} / \mathrm{L}$. Parameter pengamatan meliputi preferensi (tingkat kesukaan) hama kutu putih pepaya terhadap aroma minyak serai wangi, daya repelensi, keperidian, serta tingkat kematian (mortalitas) hama kutu putih dengan pemberian minyak sereh wangi. Hasil penelitian menunjukkan bahwa minyak sereh wangi berpotensi digunakan untuk pengendalian hama kutu putih pepaya. Aplikasi minyak sereh wangi pada konsentrasi $0.5,1$ dan $2 \mathrm{~mL} / \mathrm{L}$ menunjukkan aktivitas repelen (penolak) terhadap kutu putih, menurunkan angka keperidian dan menyebabkan kematian (mortalitas). Semakin tinggi konsentrasi minyak sereh wangi yang diaplikasikan, semakin berpotensi mengendalikan hama kutu putih. Namun, aplikasi minyak serai wangi harus diperhatikan dampaknya pada tanaman. Konsentrasi terlalu tinggi bisa menyebabkan toksisitas pada tanaman.

Kata kunci: Kutu putih, minyak sereh wangi, pepaya

\section{PENDAHULUAN}

Kutu putih, Paracoccus marginatus Linnaeus (Hemiptera: Pseudococidae) merupakan salah satu hama yang saat ini banyak dilaporkan menyerang tanaman pepaya (Carica papaya Linnaeus), seperti di Bogor (Ivakdalam, 2010), dan Sumatera selatan (Thalib et al., 2014). Kutu putih ini bersifat polifag, ditemukan berkoloni pada bagian daun dan buah pepaya, serta menginfestasi beberapa spesies tanaman lainnya (Thalib et al., 2014). Infestasi kutu putih dapat menurunkan nilai produksi dan kualitas buah karena menghisap cairan pada kelopak bunga, daun dan buah, sehingga mengakibatkan bagian tumbuhan yang dihisap menguning dan lama kelamaan gugur (Ivakdalam, 2010). Serangan pada buah yang belum matang menyebabkan buah terbentuk tidak sempurna dan menghitam ditutupi embun jelaga.

Upaya pengendalian kutu putih yang biasanya dilakukan petani adalah menggunakan insektisida sintetik yang kurang berwawasan lingkungan. Aplikasi insektisida sintetik yang berlebihan menimbulkan masalah bagi lingkungan, diantaranya menimbulkan resistensi, resurjensi, serta meninggalkan residu pada hasil panen dan mencemari lingkungan. Insektisida nabati merupakan salah satu strategi pengendalian hama yang ramah lingkungan yang patut dikembangkan demi terwujudnya sistem pertanian berkelanjutan. Aplikasi insektisida nabati bertujuan untuk mendapatkan produk pertanian yang sehat, aman dikonsumsi, bebas dari cemaran bahan kimia beracun, dan ramah lingkungan (Syakir, 2011). Pemanfaatan insektisida nabati seperti sereh wangi telah banyak diketahui dapat menurunkan tingkat serangan beberapa 
hama pada tanaman. Minyak sereh wangi dapat mengendalikan beberapa hama, diantaranya Helicoverpa armigera (Hasyim et al., 2010), lalat buah (Istianto, 2012), penggerek buah kakao (Wilis et al., 2013), hama penghisap buah lada, Dasynus piperis (Rohimatun dan Laba, 2013), hama penghisap buah kakao, Helopeltis antonii (Nurmansyah, 2014), penggerek buah mangga, Noorda albizonalis (Istianto dan Sumargono, 2015), dan. Plutella xylostella (Zahro et al., 2016).

Minyak sereh wangi tersusun dari beberapa senyawa yang mudah menguap (volatil), dan mempunyai tingkat persistensi rendah, sehingga aman bagi lingkungan dan produk pertanian (Isman, 2000, Hasyim et al., 2010). Minyak sereh wangi diketahui mengandung sitronella, geraniol dan sitral (Setyaningsih et al., 2005, Silva et al., 2011, Suryani dan Nurmansyah, 2013). Senyawa sitronella pada minyak sereh wangi berperan sebagai bahan insektisida yang bekerja sebagai antifeedant dan repelen. Oleh karena itu, aplikasi sereh wangi dapat menjadi alternatif yang perlu diuji keefektifannya dalam mengendalikan kutu putih pada tanaman pepaya. Tujuan dari penelitian ini adalah untuk mengetahui potensi dan mekanisme minyak sereh wangi dalam mengendalikan kutu putih pepaya, P.marginatus. Hipotesis pada penelitian yaitu aplikasi minyak sereh wangi bersifat repelen, dapat menurunkan jumlah keperidian, serta menyebabkan kematian pada kutu putih pepaya.

\section{BAHAN DAN METODE}

Penelitian dilaksanakan di laboratorium Proteksi Balitbu Tropika pada bulan Mei sampai dengan Agustus 2019. Penelitian untuk pengamatan mortalitas dan keperidian menggunakan Rancangan Acak Kelompok (RAK) dengan 4 taraf perlakuan, dengan 6 ulangan. Sedangkan untuk uji preferensi dan nilai repelensi dilakukan dengan 4 perlakuan 10 ulangan. Perlakuan terdiri atas 4 konsentrasi minyak sereh wangi, yaitu: 0 (kontrol), 0,5 mL/L, $1 \mathrm{~mL} / \mathrm{L}, \mathrm{dan} 2 \mathrm{~mL} / \mathrm{L}$. Minyak sereh wangi yang digunakan didapat dari Kebun Percobaan Laing Balitro, Sumatera Barat.

\section{Perbanyakan Kutu Putih}

Kutu putih $P$. marginatus dibiakkan dengan cara menginfestasikan imago yang diperoleh dari tanaman pepaya yang terserang kutu putih di kebun, ke tanaman pepaya yang berumur 6 minggu di rumah kasa. Serangga dibiarkan berkembang biak pada tanaman sampai jumlahnya cukup untuk pengujian.

Daun pepaya dari bibit umur 2 bulan dipetik 2 lembar bagian atas yang sudah terbuka sempurna. Daun tersebut diaplikasi dengan minyak sereh wangi sesuai dengan konsentrasi perlakuan, lalu di kering anginkan. Bagian tangkai daun dibalut tisu lembab untuk menjaga daun agar tetap segar. Selanjutnya daun yang telah disemprot minyak sereh wangi diletakkan pada kotak plastik berukuran $8 \times 15 \mathrm{~cm}$ dengan posisi berpasangan. Kombinasi perlakuan sebagai berikut: $\mathrm{A}$ $=$ Kontrol (0) - minyak serek wangi $0,5 \mathrm{~mL} / \mathrm{L} ; \mathrm{B}=$ Kontrol $(0)$ - minyak serek wangi $1 \mathrm{~mL} / \mathrm{L}$; dan $\mathrm{C}=\mathrm{Kontrol}(0)$ minyak serek wangi $2 \mathrm{~mL} / \mathrm{L}$. Pada bagian tengah kotak plastik diletakkan 10 ekor kutu putih nimfa instar 3.

\section{Parameter Pengamatan}

\section{Preferensi kutu putih}

Pengamatan tingkat preferensi dilakukan dengan cara menghitung jumlah kutu putih yang mendekat dan menempel pada daun perlakuan setelah 1 jam, 2 jam, 3 jam dan 4 jam setelah perlakuan.

\section{Repelensi}

Persentase repelensi dihitung menggunakan rumus (Hasyim et al., 2010):

$$
\text { Repelensi }=\frac{N C-N T}{N C+N T} \times 100 \%
$$

Keterangan: $\mathrm{NC}=$ jumlah serangga pada kontrol; $\mathrm{NT}=$ jumlah serangga pada perlakuan

Kriteria tingkatan repelensi: Kelas $0=$ Repelensi $<0,1 \%$; Kelas I $=$ Repelensi $0,1-20 \%$; Kelas II $=$ Repelensi 20,1 - 40\%; Kelas III = Repelensi 40,1 - 60\%; Kelas IV = Repelensi 60,1-80\%; Kelas V = Repelensi 80,1 - 100\%.

\section{Keperidian}

Tanaman pepaya berumur 2 bulan disemprot keseluruhannya dengan minyak sereh wangi sesuai perlakuan. Selanjutnya 2 ekor imago kutu putih betina diinfestasikan ke dua daun bagian atas setiap tanaman perlakuan dan dipelihara/dibiarkan sampai menghasilkan keturunan/anak. Pengamatan dilakukan dengan menghitung jumlah anak/keturunan yang dihasilkan oleh kutu putih betina pada setiap perlakuan.

\section{Mortalitas}

Metode aplikasi semprot serangga pada daun

Perlakuan semprot secara langsung pada kutu putih dilakukan dengan menggunakan nimfa instar 1/ instar 3 kutu putih pepaya. Daun pepaya diletakkan pada cawan petri yang telah dialasi tisu. Selanjutnya 10 ekor kutu putih (instar 1/instar 3) diletakkan pada masing-masing daun pepaya tersebut. Kutu putih disemprot dengan minyak sereh wangi 
sebanyak 0,5 ml menggunakan spuit sesuai perlakuan. Pengamatan dilakukan dengan menghitung jumlah kutu putih yang mati setelah disemprot minyak sereh wangi. Pengamatan mortalitas dilakukan 1 jam, 2 jam, 3 jam dan 4 jam setelah perlakuan.

Persentase mortalitas dihitung menggunakan rumus:

$P m=\frac{P k-P 0}{10-P 0} \times 100 \%$

Keterangan: $\mathrm{Pm}=$ persentase mortalitas; $\mathrm{Pk}=$ jumlah yang mati pada perlakuan; $\mathrm{P} 0=$ jumlah yang mati pada kontrol

\section{Metode aplikasi semprot daun}

Perlakuan ini juga menggunakan nimfa instar 1 dan instar 3 kutu putih pepaya. Daun pepaya di semprot sesuai perlakuan, lalu dikering anginkan. Setelah itu, daun diletakkan pada cawan petri yang telah dialasi tisu. Bagian tangkai daun ditutup dengan tisu basah untuk menjaga kesegaran daun. Selanjutnya 10 ekor kutu putih (instar 1/instar 3) diletakkan pada masing-masing daun pepaya tersebut. Pengamatan dilakukan dengan menghitung jumlah kutu putih yang mati setelah disemprot minyak sereh wangi. Pengamatan mortalitas dilakukan pada 1 jam, 2 jam, 3 jam, 4 jam, 24 jam, 48 jam dan 72 jam setelah perlakuan.

Data pengamatan dianalisis dengan analisis ragam mengggunakan aplikasi Statistik 8, dan jika terdapat pengaruh nyata dilakukan uji lanjut Beda Nyata terkecil (BNT) pada taraf 0,05.

\section{HASIL DAN PEMBAHASAN}

\section{Preferensi Kutu Putih}

Hasil pengamatan preferensi kutu putih terhadap daun pepaya setelah diaplikasi dengan minyak sereh wangi dengan konsentrasi berbeda disajikan pada Gambar 1.

Hasil uji preferensi menunjukkan bahwa kutu putih lebih banyak memilih daun yang tidak diberi minyak sereh wangi, dibandingkan daun yang diaplikasikan minyak sereh wangi. Daun pepaya yang diaplikasi dengan minyak sereh wangi dengan konsentrasi $0,5 \mathrm{~mL} / \mathrm{L}$ dan $1 \mathrm{~mL} / \mathrm{L}$ sama sekali tidak disukai oleh kutu putih pada 1 jam pertama. Daun tersebut baru mulai disukai 1-2 ekor kutu putih setelah 2-4 jam. Sementara itu, daun pepaya yang diaplikasi dengan minyak sereh wangi dengan konsentrasi $2 \mathrm{~mL} / \mathrm{L}$ sama sekali tidak disukai oleh kutu putih sejak awal sampai 4 jam setelah aplikasi. Semakin tinggi konsentrasi sereh wangi yang diaplikasikan, semakin tidak disukai oleh kutu putih. Tingkat preferensi juga menunjukkan perbedaan nyata antar waktu pengamatan.

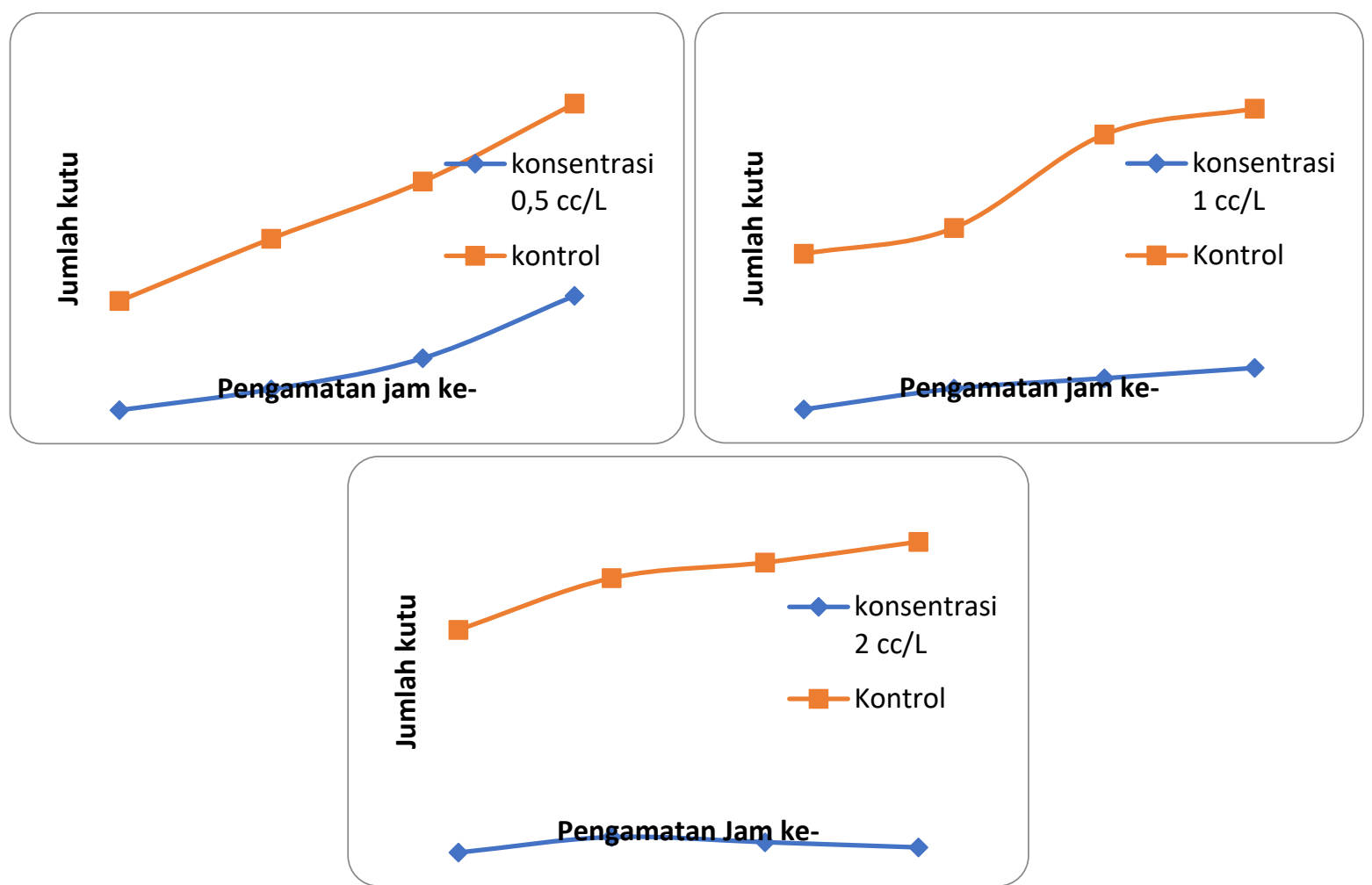

Gambar 1. Preferensi kutu putih terhadap daun pepaya setelah diaplikasi dengan minyak sereh wangi dengan konsentrasi berbeda 
Tabel 1. Repelensi kutu putih $P$. marginatus akibat perlakuan minyak serai wangi

\begin{tabular}{ccc}
\hline $\begin{array}{c}\text { Konsentrasi } \\
(\mathrm{mL} / \mathrm{L})\end{array}$ & Repelensi setelah 4 jam & Tingkat repelensi \\
\hline 0.5 & $46 \%$ & Kelas III \\
1 & $76 \%$ & Kelas IV \\
2 & $97 \%$ & Kelas V \\
\hline
\end{tabular}

Tabel 2. Pengaruh minyak sereh wangi dengan konsentrasi berbeda terhadap keperidian kutu putih pepaya

\begin{tabular}{cc}
\hline Konsentrasi $(\mathrm{mL} / \mathrm{L})$ & Keperidian (ekor) \\
\hline 0 & $311,75 \mathrm{a}$ \\
0,5 & $109,17 \mathrm{~b}$ \\
1 & $77,40 \mathrm{c}$ \\
2 & $65,83 \mathrm{~d}$ \\
\hline KK $(\mathrm{CV}) \%$ & 4,97
\end{tabular}

Keterangan: Angka-angka dalam satu kolom yang diikuti huruf kecil yang sama tidak berbeda nyata menurut uji lanjut BNT pada taraf 0,05 .

\section{Repelensi Kutu Putih}

Repelensi kutu putih pada daun pepaya setelah diaplikasi dengan minyak sereh wangi dengan konsentrasi berbeda berkisar antara 46-97\%, dengan tingkat repelensi tergolong Kelas III - Kelas V. Semakin tinggi konsentrasi minyak sereh wangi yang diberikan, semakin tinggi pula repelensi dan tingkat repelensi kutu putih terhadap daun pepaya. Aplikasi minyak sereh wangi sebanyak $2 \mathrm{~mL} / \mathrm{L}$ memberikan persentasi repelensi mencapai $97 \%$ dan tergolong kelas V (Tabel 1).

Minyak sereh wangi pada semua konsentrasi yang diuji menunjukkan aktivitas menolak (repelensi) kutu putih $P$. marginatus dengan nilai repelensi yang berbeda (Tabel 1.). Tingkat repelensi salah satunya dipengaruhi oleh konsentrasi. Karakter minyak atsiri sereh wangi yang memiliki daya penolak tinggi terhadap serangga juga ditunjukkan terhadap hama kutu putih Bemisia tabaci yang menyerang tanaman cabe (Saad et al., 2017). Menurut Burdock (2002) komponen senyawa utama minyak sereh wangi ini terdiri dari sitronelal, sitronellol, dan geraniol. Ketiga senyawa ini memiliki potensi sebagai penolak bagi serangga. Kandungan $\beta$-sitronellol dapat berperan sebagai penolak larva Spodoptera litura (Loh et al., 2011). Uap dari senyawa sitronellal telah dikenal baik sebagai penolak kehadiran nyamuk (Sakulku et al., 2009). Muller et al., (2009) menginformasikan bahwa geraniol memiliki aktivitas penolak terhadap nyamuk lebih tinggi dibanding sitronella dan linalool yaitu sampai 97\%. Aroma minyak sereh wangi mengacaukan aroma penarik yang dikeluarkan oleh tanaman inang sehingga pergerakan hama menuju tanaman inang tersebut dapat dialihkan.

Selain sitronella, minyak sereh wangi diketahui mengandung geraniol dan sitral (Setyaningsih et al., 2005, Silva et al., 2011, Suryani dan Nurmansyah, 2013). Senyawa sitronella yang terdapat pada minyak sereh wangi berperan sebagai bahan insektisida yang bekerja sebagai antifeedant dan repelen. Nurmansyah (2011) menyatakan bahwa sereh wangi bersifat repelen terhadap hama penghisap buah kakao Helopeltis antonii. Hal ini didukung oleh Rohimatun dan Laba (2013) yang menyatakan bahwa minyak sereh wangi bersifat repelen (menolak) kehadiran D.piperis untuk hinggap dan menyerang buah lada. Setyanigsih et al., (2005) dan Kongkaew et al., (2011) juga menyatakan bahwa minyak sereh wangi bersifat repelen terhadap nyamuk Aedes, Anopheles dan Culex. Sereh wangi diketahui juga bersifat repelen terhadap larva hama gudang bawang merah Ephestia cautella (Hasyim et al., 2014).

\section{Keperidian}

Berdasarkan hasil pengamatan diketahui bahwa aplikasi penyemprotan minyak sereh wangi dapat menurunkan keperidian atau jumlah keturunan hama kutu putih pepaya. Semakin tinggi konsentrasi minyak serai wangi yang diberikan, semakin rendah keperidian. Keperidian terendah ditemukan pada konsentrasi $2 \mathrm{~mL} / \mathrm{L}$, yaitu sebanyak 65,83 ekor.

\section{Mortalitas Kutu Putih dengan Metode Semprot Langsung ke Serangga}

Pengamatan terhadap mortalitas kutu putih instar 1 ini dilakukan selama 4 jam setelah aplikasi minyak sereh wangi pada serangga dengan konsentrasi yang berbeda. Pada 1 jam pertama, semakin tinggi konsentrasi minyak sereh wangi yang diberikan, semakin tinggi pula mortalitas kutu putih instar 1, kecenderungan tersebut menurun setelah 2-3 jam. Setelah 4 jam aplikasi, seluruh kutu putih instar 1 mati dan perbedaan konsentrasi tidak lagi berpengaruh secara signifikan (Gambar 2a). Pengamatan terhadap mortalitas juga dilakukan terhadap kutu putih instar 3. Pada pengamatan 1-3 jam 
setelah aplikasi, semakin tinggi konsentrasi minyak sereh wangi yang diaplikasikan, semakin tinggi pula mortalitas kutu putih instar 3. Kecenderungan tersebut menurun setelah 2-3 jam. Setelah 4 jam, seluruh kutu putih instar 3 mati dan perbedaan konsentrasi tidak lagi berpengaruh secara signifikan (Gambar 3a).

\section{Mortalitas Kutu Putih dengan Metode Aplikasi ke Daun Pepaya}

Pengamatan terhadap mortalitas kutu putih instar 1 ini dilakukan sampai 72 jam setelah aplikasi minyak sereh wangi pada daun pepaya degan konsentrasi yang berbeda. Pada 1 jam pertama, tidak ada kutu putih pepaya yang mati. Pengaruh perbedaan konsentrasi baru terlihat setelah 2 jam, semakin tinggi konsentrasi maka semakin tinggi pula mortalitas kutu putih pepaya. Setelah 72 jam aplikasi, seluruh kutu putih instar 1 mati dan perbedaan konsentrasi tidak lagi berpengaruh secara signifikan. Aplikasi minyak sereh wangi $2 \mathrm{~mL} / \mathrm{L}$ telah mematikan seluruh kutu putih sejak 24 jam pertama (Gambar 2b).
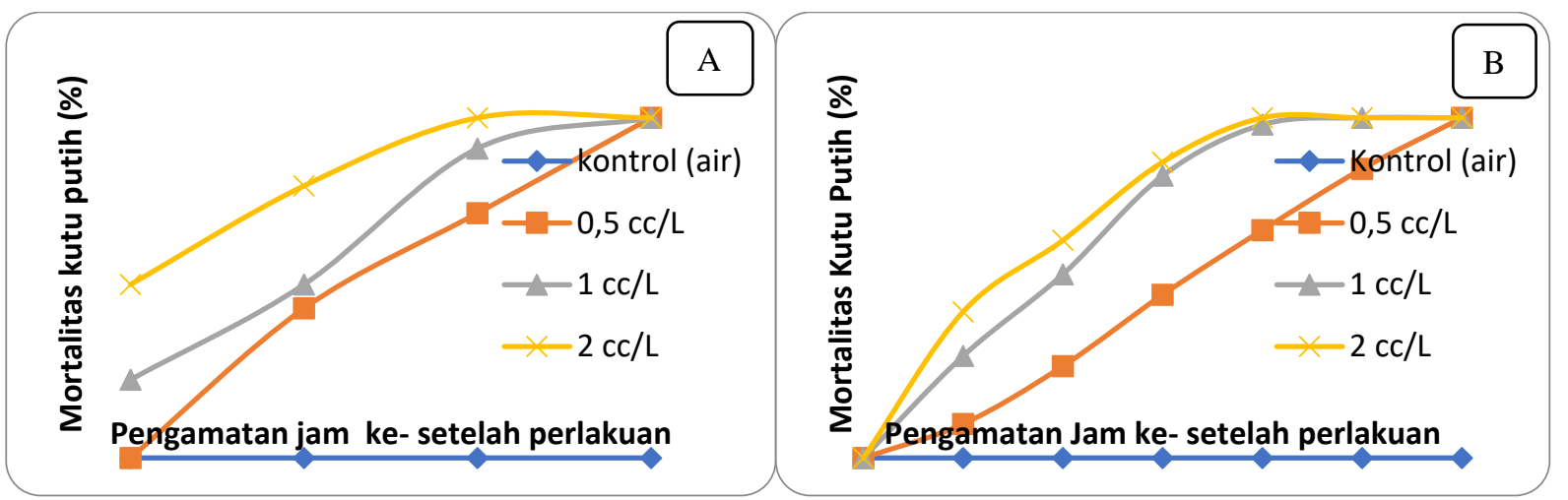

Gambar 2. Pengaruh minyak sereh wangi terhadap mortalitas instar 1 kutu putih pepaya; a) metode semprot langsung serangga pada daun, b) metode semprot daun.

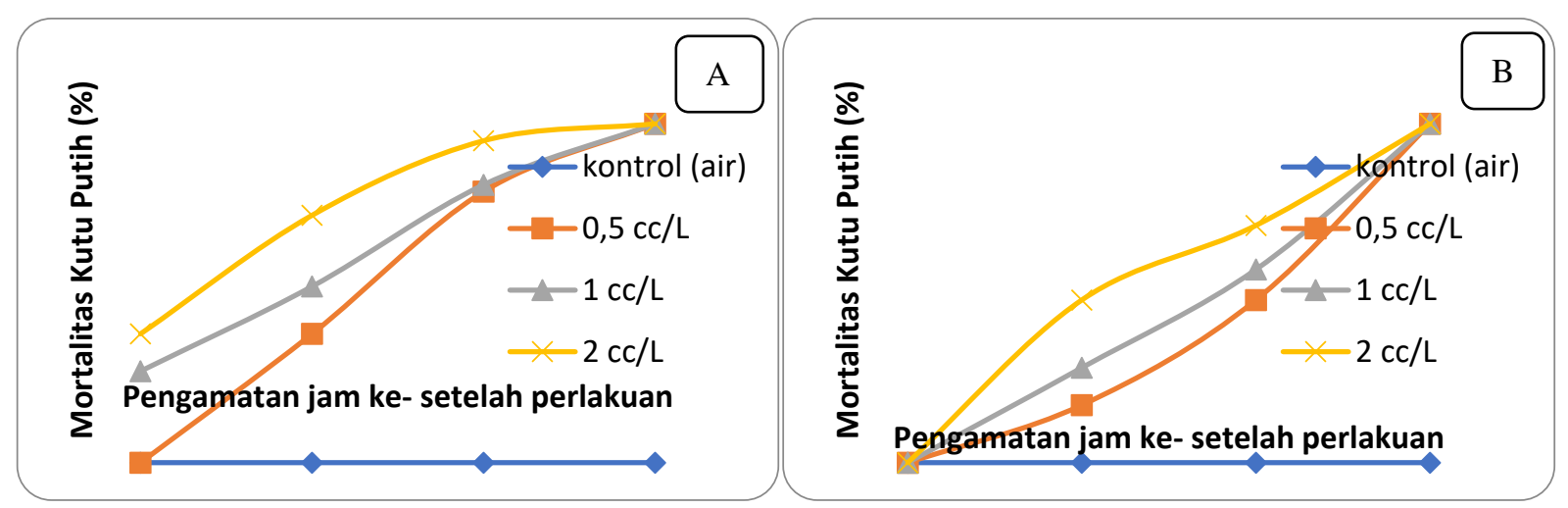

Gambar 3. Pengaruh minyak sereh wangi terhadap mortalitas instar 3 kutu putih pepaya; a) metode semprot langsung serangga pada daun, b) metode semprot daun

Pengaruh minyak sereh wangi dengan konsentrasi berbeda yang diaplikasi melalui metode semprot daun terhadap mortalitas juga dilakukan terhadap kutu putih pepaya instar 3. Pada pengamatan 1 jam pertama, tidak ditemukan pengaruh aplikasi tersebut. Pengaruh aplikasi baru terlihat setelah 24-48 jam, semakin tinggi konsentrasi minyak sereh wangi yang diaplikasikan, semakin tinggi pula mortalitas kutu putih instar. Setelah 72 jam, seluruh kutu putih instar 3 mati dan perbedaan konsentrasi tidak lagi berpengaruh secara signifikan (Gambar 3b).

\section{Pembahasan}

Hasil pengamatan uji preferensi menunjukkan bahwa kutu putih lebih banyak memilih daun yang tidak diberi minyak sereh wangi, dibandingkan daun yang diaplikasikan minyak sereh wangi. Hal ini menunjukkan bahwa kutu putih kurang menyukai aroma dari minyak serai wangi, baik konsentrasi yang tinggi $2 \mathrm{~mL} / \mathrm{L}$ maupun konsentrasi terendah 0,5 $\mathrm{mL} / \mathrm{L}$ (Gambar 1). Semakin tinggi konsentrasi sereh wangi yang diaplikasikan, semakin tidak disukai oleh kutu putih. Tingkat preferensi juga menunjukkan perbedaan nyata antar waktu pengamatan.

Minyak sereh wangi pada semua konsentrasi yang diuji menunjukkan aktivitas menolak (repelensi) kutu putih $P$. marginatus dengan nilai repelensi yang berbeda (Tabel 1). Tingkat repelensi salah satunya dipengaruhi oleh konsentrasi. 
Minyak sereh wangi diketahui mengandung methyl heptanon dan sitronella yang bersifat repelent (penolak) serangga (Souza and Couto, 2004, Koul et al., 2008, Nurmansyah, 2011, Istianto, 2012, Wany et al., 2013). Aroma minyak sereh wangi mengacaukan aroma penarik yang dikeluarkan oleh tanaman inang, sehingga pergerakan hama menuju tanaman inang tersebut dapat dialihkan.

Selain sitronella, minyak sereh wangi diketahui mengandung geraniol dan sitral (Setyaningsih et al., 2005, Silva et al., 2011, Suryani and Nurmansyah, 2013, Wany et al., 2013). Senyawa sitronella yang terdapat pada minyak sereh wangi berperan sebagai bahan insektisida yang bekerja sebagai antifeedant dan repelent. Nurmansyah (2011) menyatakan bahwa sereh wangi bersifat repelen terhadap hama penghisap buah kakao Helopeltis antonii. Hal ini didukung oleh Rohimatun dan Laba (2013) yang menyatakan bahwa minyak sereh wangi bersifat repelen (menolak) kehadiran D. piperis untuk hinggap dan menyerang buah lada. Setyanigsih et al., (2005) dan Kongkaew et al., (2011) juga menyatakan bahwa minyak sereh wangi bersifat repelen terhadap nyamuk Aedes, Anopheles dan Culex. Sereh wangi diketahui juga bersifat repelen terhadap larva hama gudang bawang merah Ephestia cautella (Hasyim et al. 2014).

Hal sebagaimana diuraikan sebelumnya dikarenakan sitronella yang terdapat pada minyak sereh wangi bersifat antifeedant, yang menyebabkan pengurangan nafsu makan serangga, sehingga jumlah konsumsi serangga pada tanaman inang menjadi berkurang. Hal ini akan mengganggu pertumbuhan dan menurunkan daya reproduksi serangga. Menurunnya angka keperidian akan menekan laju pertumbuhan populasi serangga. Wilis et al., 2013 dan Wany et al., (2013) menyatakan bahwa minyak sereh bersifat repelen, antifeedant dan deterrent oviposisi pada serangga. Setiawati et al., (2011) dan Hasyim et al., (2014 )juga menyatakan bahwa minyak serai wangi bersifat deterent oviposisi, dapat mengurangi jumlah telur yang dihasilkan Helicoverpa armigera dan Ephestia cautella.

Aplikasi sereh wangi konsentrasi $2 \mathrm{~mL} / \mathrm{L}$ dapat menyebabkan kematian 100\% kutu putih nimfa instar 3 pada 4 jam setelah aplikasi dengan menggunakan metode semprot serangga pada daun, dan 72 jam setelah aplikasi dengan menggunakan metode semprot daun. Dari hasil pengamatan tampak bahwa nimfa instar 1 kutu putih lebih cepat mati dibanding nimfa instar 3. Hal ini menunjukkan bahwa masing-masing stadia nimfa mempunyai kepekaan yang berbeda terhadap minyak sereh wangi. Kepekaan yang berbeda itu kemungkinan disebabkan karena nimfa instar 1 mempunyai ukuran lebih kecil dan tubuhnya belum dilindungi oleh lapisan lilin berwarna putih, sedangkan nimfa instar 3 mempunyai ukuran lebih besar dan telah dilindungi oleh lapisan lilin berwarna putih.

Dari beberapa hasil penelitian diketahui bahwa minyak sereh wangi menyebabkan mortalitas pada serangga, diantaranya: Helopeltis antonii (Nurmansyah, 2011), Diconocoris hewetti (hama penghisap bunga lada) sebesar 47\% pada konsentrasi 2,5\% (Wiratno et al., 2011), mortalitas lebih dari 50\% dan mengurangi populasi D.piperis di lapang dengan konsentrasi aplikasi 5 ml/L (Rohimatun dan Laba, 2013).

Minyak sereh wangi dapat menyebabkan kematian pada kutu putih dalam waktu beberapa jam atau hari tergantung dari konsentrasi yang digunakan. Semakin tinggi konsentrasi yang digunakan, semakin cepat menyebabkan kematian pada kutu putih. Gambar 2a menunjukkan bahwa aplikasi sereh wangi konsentrasi 1 dan $2 \mathrm{~mL} / \mathrm{L}$ dengan metode semprot serangga pada daun telah dapat membunuh nimfa instar 1 kutu putih pada 1 jam setelah aplikasi. Minyak sereh wangi konsentrasi $2 \mathrm{~mL} / \mathrm{L}$ lebih efektif karena membunuh 100\% kutu putih pada 3 jam setelah aplikasi. Sedangkan dengan metode semprot daun, sereh wangi pada konsentrasi $2 \mathrm{~mL} / \mathrm{L}$ dapat membunuh $100 \%$ kutu putih pada 24 jam setelah aplikasi (Gambar 2b). Metode semprot kutu lebih cepat menyebabkan kematian pada kutu dibanding metode semprot daun, karena metode penyemprotan kutu langsung mengenai integumen serangga. Minyak sereh wangi mempunyai efek iritasi sehingga menyebabkan kerusakan pada integumen dan terjadi proses transpirasi tinggi. Hal ini dapat mengakibatkan kematian pada serangga tersebut.

Hal yang sama juga tampak pada pengujian sereh wangi pada nimfa instar 3 kutu putih. Aplikasi sereh wangi dengan metode semprot kutu pada daun lebih cepat menyebabkan kematian pada kutu putih dibandingkan metode semprot daun (Gambar 3). Aplikasi sereh wangi konsentrasi $2 \mathrm{~mL} / \mathrm{L}$ dapat menyebabkan kematian 100\% kutu putih nimfa instar 3 pada 4 jam setelah aplikasi dengan menggunakan metode semprot serangga pada daun, dan 72 jam setelah aplikasi dengan menggunakan metode semprot daun. Dari hasil pengamatan tampak bahwa nimfa instar 1 kutu putih lebih cepat mati dibanding nimfa instar 3. Hal ini menunjukkan bahwa masing-masing stadia nimfa mempunyai kepekaan yang berbeda terhadap minyak sereh wangi. Kepekaan yang berbeda itu kemungkinan disebabkan karena nimfa instar 1 mempunyai ukuran lebih kecil dan tubuhnya belum dilindungi oleh lapisan lilin berwarna putih, sedangkan nimfa instar 3 mempunyai ukuran lebih besar dan telah dilindungi oleh lapisan lilin berwarna putih.

Minyak sereh wangi dapat menyebabkan kematian pada serangga, karena bersifat racun kontak yang menyebabkan gangguan pada sistem saraf pusat serangga (Rohimatun dan Laba, 2013). Senyawa citronellal yang terkandung dalam minyak sereh wangi merupakan racun kontak yang masuk ke dalam tubuh serangga melalui integumen atau lubanglubang alami dari tubuh serangga. Setelah masuk, racun akan menyebar ke seluruh tubuh serangga dan menyerang sistem syaraf sehingga menyebabkan gangguan pada aktivitas serangga dan serangga akan mati (Setyaningrum, 2007). Prijono (1994) menyatakan bahwa penyerapan pestisida yang mempunyai efek racun kontak sebagian besar terjadi pada kutikula. Senyawa aktif akan berpenetrasi ke dalam tubuh serangga melalui kutikula, menuju hemolimpa, dan disebarkan ke seluruh tubuh sehingga lama kelamaan serangga akan kehilangan cairan dan akhirnya mengalami kematian.

Senyawa citronella juga bekerja sebagai racun perut pada serangga yang menghisap cairan daun yang telah disemprot dengan minyak sereh wangi. Cairan tersebut masuk ke saluran pencernaan melalui kerongkongan serangga yang akan mengakibatkan menurunnya aktivitas makan kutu putih pepaya, gerakan menjadi lambat, dan akhirnya mati. 
Sesuai dengan hasil penelitian Fikri et al. (2010), yang menyatakan bahwa senyawa sitronella bersifat racun perut yang dapat membunuh thrips pada tanaman jarak pagar.

\section{KESIMPULAN}

Minyak sereh wangi berpotensi sebagai biopestisida untuk mengendalikan hama kutu putih pepaya melalui mekanisme repelent (penolak), menurunkan keperidian dan menyebabkan kematian pada hama kutu putih. Semakin tinggi konsentrasi minyak sereh wangi yang diaplikasikan, semakin menurunkan tingkat preferensi, jumlah keperidian, dan meningkatkan persentase mortalitas kutu putih pepaya.

\section{UCAPAN TERIMA KASIH}

Ucapan terima kasih disampaikan kepada Putri dan Zulfan yang telah membantu dalam pelaksanaan kegiatan penelitian ini.

\section{DAFTAR PUSTAKA}

Burdock, G. 2002. Fanarali's Handbook of Flavor Ingredients. Boca Raton, FL, CRC Press. DOI: https://doi.org/10.1201/ NOE0849309465.

Hasyim, A., W. Setawati, H. Jayanti, dan E. H. Krestini. 2014. Repelensi Minyak Atsiri Terhadap Hama Gudang Bawang Merah Ephestia cautella (Walker) (Lepidoptera: Pyrallidae) di Laboratorium. Hortikultura 24 (4): 336-345. DOI: https://doi.org/10.21082/jhort.v24n4.2014.p336-345.

Hasyim, A., W. Setawati, R. Murtiningsih,. dan E. Sofiari. 2010. Efikasi dan Persistensi Minyak Serai Wangi sebagai biopestisida terhadap Helicoverpa armigera Hubner (Lepidoptera: Noctuidae). Jurnal Hortikultura 20(4): 377-386.

Isman, M. B. 2000. Plant Essential Oils For Pest and Diseases Management. Crop Prot. 19:603-608. DOI: https://doi.org/ 10.1016/S0261-2194(00)00079-X.

Istianto, M. 2009. Pemanfaatan minyak atsiri, Alternatif teknologi pengendalian organisme pengganggu tanaman buah yang ramah lingkungan. IPTEK Hortikultura 5:34-38.

Kongkaew, C., I. Sakunrag, N. Chaiyakunapruk, dan A. Tawatsin. 2011. Effectiveness of Citronella preparations in preventing mosquito bites: Systematic review of controlled laboratory experimental studies. Tropical Medicine and International Health 16 (7): 802-810. DOI: https://doi.org/10.1111/j.1365-3156.2011.02781.x.

Loh, S.W, R.M. Awang, D. Omar,.and M. Rahmani. 2011. Insecticidal properties of Citrus hystrix DC leaves essential oil against Spodoptera litura fabricius. Journal of Medicinal Plants Research 5(16): 37- 39.

Muller, G, J. Butler, A. Junnila, and V. Kravchenko. 2009. Efficacy of the Botanical Repellents Geraniol, Linalool, and Citronella Against Mosquitoes. Journal of Vector Ecology 34(1):2-8. DOI: https://doi.org/10.1111/j.1948-7134.2009.00002.x.

Nurmansyah. 2014. Pengaruh interval aplikasi dan waktu penyemprotan pestisida nabati serai wangi terhadap hama Helopeltis antonii pada tanaman kakao. Buletin Penelitian Tanaman rempah dan Obat 25 (1): 53-60. DOI: https://doi.org/ 10.21082/bullittro.v25n1.2014.53-60.

Rohimatun, dan I.W.Laba. 2013. Efektifitas insektisida minyak sereh wangi dan cengkeh terhadap hama penghisap buah lada. Buletin Penelitian Tanaman rempah dan Obat 24 (1): 26-34. DOI: http://dx.doi.org/10.21082/bullittro.v24n1.2013.\%25p.

Saad, K. A, A. B. Idris, and M. N. Mohammad Roff. 2017. Toxic, Repellent, and Deterrent Effects of Citronella Essential Oil on Bemisia tabaci (Hemiptera: Aleyrodidae) on Chili Plants. Journal of Entomological Science 52(2):1-12. DOI: https://doi.org/10.18474/JES16-32.1.

Sakulku, U., O. Nuchuchua, N. Uawongyart, S. Puttipipatkhachorn., A. Soottitantawat, U. Ruktanonchai. 2009. Characterization and mosquito repellent activity of citronella oil nanoemulsion. Int. J. Pharm. 372:105-111. DOI: https://doi.org/10.1016/ j.ijpharm.2008.12.029.

Setiawati, W., Murtingingsih, R., dan Hasyim A. 2011. Laboratory and field evaluation of essential oils from Cymbopogon nardus as oviposition deterrent and ovicidal activities against Helicoverpa armigera Hubner on chili pepper. Journal of Agricultural Sciences 12(1):.9-16. https://doi.org/10.21082/ijas.v12n1.2011.p9-16.

Setyaningsih, D., E. Hambali, dan M. Nasution. 2005. Aplikasi minyak sereh wangi (Citronella Oil) dan Geraniol dalam pembuatan Skin Lotion penolak nyamuk. Jurnal Teknik Industri Pertanian 17(3): 97-103.

Silva, C. F., F. C. Moura, M. Merndes, dan F. Pessoa. 2011. Extraction of Citronella Brazilian (Cymbopogon nardus) essential oil using supercritical $\mathrm{CO}_{2}$ : Experimental Data and Mathematical Modelling. Journal of Chemical Engineering 28 (2): 343-350. https://doi.org/10.1590/S0104-66322011000200019.

Suryani, E. dan Nurmansyah. 2013. Penampilan Beberapa klon unggul serai wangi pada dua agroekologi berbeda di Sumatera barat. Buletin Penelitian Tanaman rempah dan Obat 24(2): 73-78. DOI: http://dx.doi.org/10.21082/bullittro.v24n2.2013.\%25p

Syakir, M. 2011. Status Penelitian Pestisida Nabati Pusat Penelitian dan Pengembangan Tanaman Perkebunan. Prosiding Semnas Pesnab IV, Jakarta 15 Oktober 2011. Balitro, Bogor.

Wilis, M., I. W. Laba, Rohimatun. 2013. Efektifitas Insektisda Sitonella, Eugenol dan Azadirachtin Terhadap Hama Penggerek Buah Kakao. Buletin Penelitian Tanaman rempah dan Obat 24(1): 19-25. DOI: http://dx.doi.org/10.21082/bullittro.v24n1. 2013.\%25p.

Wiratno, Siswanto, Luluk, dan S. Suriati. 2011. Efektifitas Beberapa Jenis Tanaman Obat dan Aromatik Sebagai Insektisida Nabati Untuk Mengendalikan Diconocoris hewetti dist (Hemiptera:Tingidae). Buletin Penelitian Tanaman rempah dan Obat 22(2): 198-204. DOI: http://dx.doi.org/10.21082/bullittro.v22n2.2011.\%25p. 
Zahro, F. A., T. Himawan, dan G.Mudjiono. 2016. Uji Bioaktivitas Ekstrak daun sereh wangi terhadap Plutella xylostella Linnaeus. Jurnal HPT 4(2): 85-92. ISSN: 2580-6459. 